\title{
Erich Przywara o reformaciji
}

\author{
IVICA RAGUŽ゙* \\ • https://doi.org/10.31823/d.27.2.1 • \\ UDK: 274-05 Przywar, E. • Izvorni znanstveni rad \\ Primljeno: 11. siječnja 2019. • Prihvaćeno: 13. lipnja 2019.
}

Sažetak: U članku se predstavljaju promišljanja Ericha Przyware o reformaciji. U prvom dijelu donosi se Przywarino razumijevanje reformacije u ranijim djelima pod vidom $\gg$ Jedino Bog sve «, odnosno reformacija shvaćena kao »teopanizam $<$. Za njemačkoga teologa takav pristup dovodi do antropocentrizma i kozmocentrizma, do ukidanja Boga, poistovjećivanja Boga s čovjekovim ja ili pak sa svijetom. Drugi dio analizira kritiku reformacije u kasnijim djelima Ericha Przyware. Dotiču se i njegova promišljanja o analogiji, katoličkoj kristologiji i mariologiji kao odgovor na teološke postavke reformacije. U trećem dijelu predstavlja se pozitivno tumačenje reformacije i teologije Martina Luthera. Przywara shvaća reformaciju kao korektiv katolicizmu, ali i kao izazov, koji u ekumenskom dijalogu s katolicizmom, shvaćenom kao dijalog razlika $i$ oprječnosti, može

* Prof. dr. sc. Ivica Raguž, pripomoći novoj obnovi i životnosti kršćanstva, napose u Europi.

Katolički bogoslovni fakultet u Đakovu

Sveučilišta J.J.

Strossmayera u Osijeku, P. Preradovića 17, p. p. 54, 31400 Đakovo, ivica.raguz@os.t-com.hr

Ključne riječi: Erich Przywara, reformacija, Martin Luther, katolicizam, protestantizam, novovjekovlje.

Njemački teolog i isusovac Erich Przywara jedan je od najutjecajnijih teologa prošloga stoljeća. Dovoljno je samo spomenuti njegov golem utjecaj na dvojicu njegovih učenika, Karla Rahnera i Hansa Ursa von Balthasara. Tako Hans Urs von Balthasar za Przywaru kaže da se u njegovoj teologiji »može slušati riječ 'Bog' bez lagane mučnine, koju uzrokuje mlako blebetanje naše prosječne teologije $\ll^{1}$. Posebno je poznat Przywarin nauk o analogiji, na cijem temelju ili ritmu on razrađuje cijelu svoju teologiju. Čuvena je također i kritika Karla Bartha koji katolički (Przywarin) nauk o analogiji smatra djelom Antikrista. Osim analogije

${ }^{1}$ H. U. v. BALTHASAR, E. Przywara, u: H. J. SCHULTZ, Tendenzen der Theologie im 20. Jahrhundert, Stuttgart - Olten, 1966., 354s. 
Przywara je promišljao gotovo sve teološke teme, a uz to je vodio intenzivan, ali i kritički dijalog s cijelom novovjekovnom kulturom, napose s filozofima novovjekovlja. Malo tko je uspijevao jasnoćom i velikom intuitivnošću predstaviti određenu misao autora te ju istodobno promotriti s kršćanskoga gledišta. Premda Przywara nije ostavio opsežan opus, njegova misao predstavlja poteškoće u razumijevanju jer mnoga promišljanja ostaju samo fragmentarna ili pak intuitivna, bez opsežnih referenci i tumačenja. To vrijedi gotovo za sve teme, pa tako i za temu reformacije.

Reformacija je stalna tema u cjelokupnom opusu našega pisca, od najranijih djela pa sve do posljednjih. Posve je razumljivo da je reformacija stalna tema jer Przywara tumači svoj nauk o analogiji upravo nasuprot reformaciji. Osim toga duh reformacije njemački teolog primjećuje u novovjekovnim filozofijama, kao i u cjelokupnoj modernoj kulturi. U tom je smislu za Przywaru reformacija ključ za razumijevanje novovjekovnoga doba, ali i način da se upozori na posebnost katolicizma i katoličke teologije. Premda u njegovoj interpretaciji uglavnom prevladava kritika reformacije, u kasnijem razdoblju Przywara uočava mnogobrojne pozitivne vidove reformacije. Posebice se to tiče teologije Martina Luthera, kod kojega uviđa ono što će osobito njemu biti važno u razumijevanju otajstva Božjega utjelovljenja u Isusu Kristu, a to je commercium admirabile. Kako ćemo pokazati, njemačkomu teologu Lutherova teologija ne služi samo kao nadahnuće nego također i kao kritika modernih teologija u protestantizmu i katolicizmu. Drugi pozitivni vid reformacije za Przywaru sastoji se u tome da je ona poništila pogrješan, odnosno ohol način ostvarenja kršćanske vjere u Europi te predstavlja neku vrstu poniženja istoga ohologa kršćanstva, ali i poticaj da Katolička Crkva i reformacija, sada u uzajamnom dijalogu, počnu živjeti drukčije, poniznije, kršćansku vjeru. U tome se krije velik ekumenski doprinos Przywarina razumijevanja reformacije.

No Przywara ne temelji ekumenski dijalog na prešućivanju razlika, nego, naprotiv, na dijalogu u kojem obje strane otvoreno progovaraju o razlikama, razlikama koje potvrđuju posebnost svake strane u ekumenskom dijalogu, u kojem se isključuje svaki sinkretizam, jeftin kompromis koji bi zapravo svjedočio o neozbiljnom stavu spram onoga što se živi, svjedoči i vjeruje. Ekumenski dijalog, koji je za njega uvijek dijalog u razlikama, Przywara shvaća kao uzajamno služenje (upravo u tim razlikama), gdje Katolička Crkva služi reformaciji, a reformacija Katoličkoj Crkvi, i to tako da one obje to služenje shvaćaju kao služenje jednomu Gospodinu koji služi: »U svakoj boli zbog podjele kršćanstva stajati u jasnim, neizbrisivim razlikama: jer takvo stajanje u misteriju razlika i oprječnosti, jest jedino služeće stajanje u otajstvu neistraživoga Gospodina koji služi. ${ }^{2}$

${ }^{2}$ E. PRZYWARA, Gespräch zwischen den Kirchen. Geführt von E. Przywara und Hermann Sauer, Zürich, 1956., 106. 
U prvom dijelu članka prikazat ćemo Przywarinu kritiku reformacije u ranim djelima, u drugom dijelu u kasnim djelima. U trećem dijelu predstavit ćemo Przywarino pozitivno, ekumensko tumačenje reformacije, kao i teologije Martina Luthera. ${ }^{3}$ Treba imati na umu da je Przywarino poimanje reformacije još uvijek u katoličkoj teologiji nedovoljno istraženo, tako da se ovaj rad shvaća kao početnički koji bi trebao pokrenuti nova istraživanja.

\section{Reformacija $\gg$ jedino Bog sve $\ll$}

U Przywarinim ranijim djelima temeljna teza o reformaciji, koja se neprestance provlači, a nastavlja se i u kasnijem opusu, glasi: $\gg$ jedino Bog sve $\ll$, odnosno $\gg$ teopanizam $\ll$. Ta teza stvara dojam da reformacija nema nikakve veze s tzv. posvjetovnjačenjem ili počovječenjem Boga, kako to tvrdi Przywara. No upravo se to i dogodilo s reformacijom. Naime teza $\gg$ jedino Bog sve $\ll$ donosi ideju radikalnoga proturječja između Boga i svijeta-čovjeka. Takvo razumijevanje odnosa Boga i svijeta, Boga i čovjeka uzrokuje deizam-ateizam s jedne strane ili pak panteizam s druge strane. Oba svjetonazora izričaji su toga teopanizma, jer je svijet-čovjek u teopanizmu prepušten samomu sebi, što dovodi do deizma ili ateizma, gdje je Bog bez svijeta i svijet bez Boga. S druge pak strane, kako ćemo to još pokazati, događa se krajnje stapanje Boga sa svijetom-čovjekom, što je slučaj s panteizmom, jer se načelo »jedino Bog « premješta u čovjekovu nutrinu ili se poistovjećuje s idejom svijeta. ${ }^{4}$

Oba pristupa Przywara uočava u novovjekovnoj filozofiji. Novovjekovnu filozofiju dijeli u dvije temeljne skupine, a to su antropocentrizam i kozmocentrizam. U prvoj se skupini polazi od čovjeka, a kao primjer naš pisac uzima Kanta. U antropocentrizmu polazište za mišljenje i razumijevanje Boga jest čovjekovo ja. Čovjekovo ja u takvoj je filozofiji podijeljeno: s jedne strane ono je tzv. ograničeno, empirijsko $j a$, a s druge strane ono je transcendentalno $j a$, koje predstavlja »ćudoredni ideal «. Takav rascjep, zapravo, prema Przywari, samo izriče reformacijsko razumijevanje odnosa Boga i čovjeka: potpuno sveti Bog i potpuno čovjek grješnik. Sada se to reformacijsko shvaćanje Boga i čovjeka u antropocentrizmu interiorizira, premješta se u čovjekovu nutrinu. No tu se događa redukcija Boga na njegovu nutrinu, na humanost: odnos prema Bogu jest odnos prema sebi, ulogu Boga preuzima idealno, transcendentalno ja, a grješno ja jest ono empirijsko ja.

\footnotetext{
${ }^{3}$ Od mnogobrojne literature o Erichu Przywari izdvajamo: B. GERTZ, Glaubenswelt als Analogie. Die theologische Analogielehre Erich Przywaras und ihr Ort in der Auseinandersetzung um die analogia fidei, Düsseldorf, 1969.; S. LÜTTICH, Nach-Erfahrung. Theologische Dimensionen einer Metapher, Würzburg, 2004., 242-299.; E. M. FABER, Künder der lebendigen Nähe des unbegreiflichen Gottes, u: M. STRIET, J.-H. TÜCK (prir.) Die Kunst Gottes verstehen. Hans Urs von Balthasars theologische Provokationen, Freiburg, 2005., 384-409.
}

${ }^{4}$ E. PRZYWARA, Der katholische Gedanke, Köln - München - Wien, 1926., 37. 
U kozmocentrizmu se pak polazi od kozmosa te se unutar kozmosa misli Boga, pri čemu opet dolazi do redukcije Boga, ovaj put na kozmos. Przywara razlikuje nekoliko podskupina kozmocentrizma. Prva podskupina jest ona koja označava kozmos kao nešto pozitivno, u smislu da on izriče »rastući sve-život «, kozmos shvaćen kao pathos rasta. U takvoj je viziji čovjek pojedinac tu sporedan, važno je ono što je iznad njega. To je filozofija koja se shvaća kao pobožnost svijeta, gdje je svijet kao Bog i Bog kao svijet. I tu se također može vidjeti logika »jedino Bog sve «, gdje ulogu Boga preuzima sada kozmos kao »rastući sve-život «. Druga pak podskupina motri kozmos negativno, gdje čovjek pojedinac predstavlja kao nešto što ne treba biti, on je kao neka vrsta bolesti, od koje se treba osloboditi. Naposljetku, treća podskupina predstavlja tzv. kozmičku filozofiju polova (Simmel), gdje se individualno shvaća kao pojava krajnjih temeljnih tipova (polova) života, gdje se polovi života sudaraju ili ekstremiziraju u krajnjoj tragičnosti. Tu tragičnost naš pisac vidi također u srednjovjekovnom voluntarizmu, pretjerivanju u Božjoj volji, gdje jedino Bog djeluje, dakle opet $\gg$ jedino Bog sve $\ll^{5}$. Tako se sada tragičnost Boga, teološko $» j$ jino sve « premješta na razinu filozofije.

Antropocentrizam tako uzrokuje poistovjećivanje $\gg$ Bog-ja «, gdje čovjekovo (transcendentalno) ja postaje Bog, a kozmocentrizam pak poistovjećivanje $\gg$ Bog-svijet $\ll$, gdje sada svijet postaje Bog, odnosno Bog samovolje sada postaje svijetom samovolje. Bog je alogos, iskonska zagonetka ili tama. ${ }^{6}$

Prema našem piscu, sve navedene filozofije ukazuju na problematičnu misao reformacije. Bog se uvijek shvaća kao prokletstvo za stvorenje. Stvorenje je promašaj, dakle u krajnjoj suprotnosti s Bogom, Bog ga privlači da bi ga odbacio. U tom smislu reformaciju Przywara shvaća kao religiozni korijen bilo antropocentrizma bilo kozmocentrizma. U antropocentrizmu konkretno, empirijsko (povijesno) čovjekovo ja vezano je uz idealno ja kako bi ono bilo odbačeno. U kozmocentrizmu čovjekovo ja vezano je uz kozmički razvoj te u njemu pronalazi svoju propast.

Przywara vidi u svemu tome Boga shvaćena kao proturječje. No reformacija, prema našem piscu, samo nastavlja tu istu misao koja se već kao takva pojavljuje u antičko doba. Naime u Grka onkraj bogova nalazi se heimarmene, moira, neka vrsta sudbine spram koje sve ostaje u suprotnosti, proturječju. Ili pak kasnije u gnosticizmu, gdje se Boga stavlja u potpuno proturječje sa svijetom. Zato je reformacija, odnosno novovjekovna filozofija, ponovno oživljavanje toga načela proturječja: »Bog kao 'ne' stvorenju, stvorenje kao sudioništvo u Bogu samo u 'ne' prema samom sebi:

\footnotetext{
${ }^{5}$ Isto, 36.

${ }^{6}$ Isto, 37.
} 
Bog-život samo u stvorenju-smrt? $\ll^{7}$ To je jedan od razloga zašto Przywara primjerice u djelu Humanitas tumači Luthera upravo u kontekstu Platonove filozofije i to zajedno s gnozom i gnostičkim pokretima u srednjovjekovlju. Za Przywaru takav Bog, koji se shvaća kao Bog isključivo »iznad nas «, nužno završava s ekstremnim $\gg$ Bogom u nama «, poistovjećenjem sa stvorenim. Ili, drukčije rečeno, takva vizija Boga i svijeta kao nužnu posljedicu ima ili ateizam ili panteizam.

Načelo reformacije $\gg$ jedino Bog sve « očituje se i u shvaćanju Crkve. Tako se odbacuje vidljivost Crkve, Crkva se ukida u svojoj vidljivosti kao $\gg$ Crkva - jedino Bog $\ll$. Njemački teolog ističe kako se i tu može jasno uvidjeti da se teopanizam reformacijske ekleziologije pretvara u panteizam ekleziologije jer je Crkva sada shvaćena jednostrano i isključivo pod vidom subjekta. Naime subjekt je taj koji određuje što je zajednica, njegova savjest određuje ono što Crkva smije i treba biti: »sam s Bogom u savjesti «. Crkva tako postaje zajednica čistih, onih koji su postigli identitet s Bogom te oni određuju što i kakva Crkva smije i treba biti. ${ }^{8}$ Tako s jedne strane, gdje prevladava $\gg$ jedino Bog sve $\ll$, Crkva postaje zajednica koja je lišena svega juridičkoga, ali koja se istodobno želi osloboditi svega sektaškoga, subjektivističkoga, u smislu da ona sama određuje ono što je objektivno.

No u takvom shvaćanju Crkve sam Krist biva ugrožen, što opet pokazuje novovjekovna filozofija. Tako se Krista ukida u nekakvo transcendentno Božje djelovanje, Bog postaje ideja (njemački idealizam) ili neprepoznatljiv (Kant) ili, u konačnici, metodička granična ideja (funkcionalizam). Dakle opet reformacijsko $\gg$ jedino Bog sve « postaje »jedino čovjek sve «. To znači da ljudsko postaje božansko, bilo u formi Kantova transcendentalnoga subjekta, bilo kao Fichteova sve-volja ili pak kao Nietzscheov nadčovjek. Krist postaje običan čovjek, istaknuti primjerak čovjeka, jer svaki čovjek već u sebi nosi, kao transcendentalno ja, božansko u sebi. ${ }^{9}$ Štoviše, događa se nešto paradoksalno sa shvaćanjem Crkve. U katolicizmu Crkva ima veliko značenje (kao sakrament, Kristovo Tijelo), ali upravo njezina činjenica sakramentalnosti podrazumijeva različitost, ne-identitet Krista i Crkve, uvjetovanost Crkve Kristom. U reformaciji se pak događa suprotno, što sjajno primjećuje Przywara. Crkva postaje »zajednica $\ll$, ona, doduše, više nema sakramentalnu ulogu predstavljanja Krista, ali se zato ona u cijelosti, kao »nevidljiva zajednica «, identificira s Kristom! Sada se događa »Bog kao Crkva «, što će naš pisac vidjeti također i na političkoj razini, gdje će određena politička zajednica (nacija), na tragu reformacije, preuzeti takvu identitetsku, mesijansku ulogu zajednice nacije

\footnotetext{
${ }^{7}$ Isto, 43.

${ }^{8}$ Isto, 87.

${ }^{9}$ Isto, 65.
} 
kao Boga (nacionalizam Amerike). ${ }^{10}$ Jednom riječju, reformacijska ekleziologija u borbi protiv sakramentalizma katoličke ekleziologije završava u još daleko većem $i$ problematičnijem identitetu zajednice i Krista, gdje sada vlada ono u katolicizmu nezamislivo načelo $\gg$ Bog kao Crkva «.

Stoga, zaključuje Przywara, svi pokušaji moderne teologije, ekleziologije završavaju u identitetu, $\mathrm{u}$ individualnoj religioznosti ili individualno uvjetovanom zajedništvu. ${ }^{11}$ Przywara je savršeno uvidio da se to isto može primijetiti i kod Bartha, premda je njegova nakana bila prevladavanje subjektivne religioznosti. Naime, kako Bog čovjeka iznutra ne mijenja, kako čovjek u svojoj nutrini i dalje ostaje u svojem ja, u svojem identitetu, on nije realno zahvaćen i promijenjen Bogom. Čovjekova nutrina ostaje ista, nepromijenjena. ${ }^{12} \mathrm{~S}$ tom se kritikom Bartha možemo složiti. Barthova teologija samo naizgled nudi prevladavanje tzv. liberalne protestantske teologije 19. stoljeća, kao i prevladavanje svake sekularne misli. Budući da u njegovoj teologiji čovjek ne biva iznutra zahvaćen i promijenjen Bogom (kao u katolicizmu: »posvetna milost «), čovjek i dalje ostaje isti, prepušten sebi, i dalje iznutra određen isključivo sobom, a ne Bogom. Sav Barthov »Dixit Deus « ostaje izvanjski, a nutrina ostaje ista.

Przywara je vjerojatno jedan od prvih katoličkih teologa koji je uvidio taj najproblematičniji vid cijele Barthove teologije koja upravo zbog toga ostaje i dalje unutar reformacijske logike $\gg$ jedino Bog sve $\ll$, a time $\gg$ jedino čovjek sve $\ll{ }^{13}$. Dok liberalna teologija ukida Krista u običnoga čovjeka, ljudsko jest identično s božanskim, tj. panteistički »jedino čovjek sve « u sebi zapravo krije i ostvaruje $»$ jedino Bog sve «, Barthova pak teologija također je posljedica teopanizma, ali teopanizma koji sada inzistira na drugosti Boga. Bog je toliko drukčiji da čovjek i dalje ostaje kod sebe, odnosno čovjek i dalje ostaje $\gg$ jedino sve $\ll$. Tako su oba te-

\footnotetext{
${ }^{10}$ Isto, 85. Više o toj temi vidi I. RAGUŽ, Utjecaj 'američke civilne religije' u Hrvatskoj, u: ISTI, Teološki fragmenti III., Đakovo, 2017., 370-374.; ISTI, Vjernik i nevjernik pod 'unakrsnim pritiskom'. Charles Taylor o sekularnom dobu, u: ISTI, Teološki fragmenti II., Đakovo, 2017., 235-249.

${ }^{11}$ E. PRZYWARA, Der katholische Gedanke, 88.

${ }^{12}$ Isto, 89.

${ }^{13}$ To se može vidjeti i u Barthovu poimanju Blažene Djevice Marije. Barthu je Marija teološki važna samo kao Djevica, ali ne i kao Božja Majka. Naime Marijino djevičanstvo izriče Božji zahvat u povijest, novost Božjega djelovanja na čovjeku itd. No upravo Marijino majčinstvo kazuje da čovjek iznutra prima i rađa Boga, da je iznutra promijenjen i zahvaćen Bogom, a ne kao u Bartha, gdje je Marija samo izvanjski zahvaćena Bogom, a iznutra sve ostaje isto kao prije. U tom je smislu i Barthova mariologija, koliko god ona naizgled izgledala bliska katoličkoj mariologiji, krajnje reformacijska. Stoga upravo Barthova mariologija pokazuje da njegova (kalvinistička) teologija Božje veličine (»jedino Bog sve «) ništa ne mijenja u čovjeku, odnosno sve završava $u$ »jedino čovjek sve «. O Barthovoj mariologiji vidi I. PODGORELEC, Isusovo djevičansko rođenje, Marijino djevičanstvo, bezgrješno začeće i istočni grijeh u Karla Bartha, u: Diacovensia 24(2016.)3, 451-468.
} 
ološka strujanja, premda krajnje suprotstavljena, zapravo identična: »jedino Bog sve « završava $\mathrm{u} \gg$ jedino čovjek sve «. Przywara tvrdi da je upravo zbog teopanizma reformacija trajno određena krajnostima od $\gg$ pathosa ovostranosti pobožanstvenjenja stvorenja gdje se radosno pristupa kulturi do pathosa onostranosti eshatološkoga 'jedino Bog sve' $\ll{ }^{14}$

Zaključno rečeno: usmjerenje teopanizma završava u religiji nutrine, ali i nestanku samoga objekta, Bog postaje nevidljiv i apstraktan, tako da »jedino Bog sve « završava $\mathrm{u} \gg$ jedino ja sve «. Teopanizam završava, zapravo, u identitetu panteizma. $\mathrm{Nu}$ trina se uzdiže na razinu božanskoga, a takvo samopotvrđivanje nutrine u reformaciji samo je izričaj, za našega autora, »te isključive djelotvornosti koja je okrenuta prema unutra $\ll$. Covjek je sposoban za Boga, ako je jedino Bog u njemu sposoban.

Prema njemačkom teologu, slično se može vidjeti i u raznim teološkim naglascima $\mathrm{u}$ reformaciji, posebice u kalvinizmu i luteranizmu. Tako u kalvinizmu čovjekova sposobnost nije samo nutrina, nisu ni dobra djela, nego »'izljev neshvatljive volje veličanstva' « ${ }^{15}$. No u obama slučajevima, u luteranizmu i kalvinizmu, imamo ponovno reformacijsko načelo $\gg$ jedino Bog sve $\ll$, tj. proturječje između Boga i čovjeka koje opet završava u identitetu. U luteranizmu susrećemo $\gg$ transcendentnu imanenciju $\ll$, a to znači da se transcendencija reducira na imanenciju. U kalvinizmu pak imamo $\gg$ imanentnu transcendenciju $\ll$, transcendencija pogađa imanenciju. Luteranska »transcendentna imanencija « dovršava se u Hegelovoj filozofiji gdje se Božja transcendencija ukida u čovjekovoj, društvenoj imanenciji. Kalvinizam pak pokušava prevladavati imanenciju tako što se sada stavlja naglasak na krajnje Božje raspolaganje čovjekom, čovjekovo nestajanje pred Bogom sve do paradoksa. Takva misao susreće se posebice u Kierkegaarda.

Ali oba mislioca, prema njemačkom teologu, i dalje ostaju unutar reformacijskoga načela $\gg$ jedino Bog sve $\ll$. Tako se u Hegela događa apsolutiziranje imanencije, koja se poistovjećuje $s$ transcendencijom, a kod Kierkegaarda se naglašava apsolutiziranje transcendencije do krajnjega paradoksa, da više transcendencija i imanencija nemaju ništa zajedničkoga, odnosno gdje imanencija ostaje opet isključivo kod sebe, sve do paradoksa »ateizma iz očaja «. Protiv Hegela i Luthera, tvrdi Przywara, uvijek treba isticati Boga u sebi u svojoj slavi, a ne zbog čovjeka. Protiv Kierkegaarda uvijek treba vrijediti: spram opasnosti krajnje pasivnosti, zatvorenosti vlastitoga ega, nepotrebitosti vlastitoga ega, u središtu treba biti opuštenost djeteta. Dakako, premda se Hegel i Kierkegaard udaljuju od katoličkoga, obojica uviđaju, zapravo,

\footnotetext{
${ }^{14}$ E. PRZYWARA, Der katholische Gedanke, 67.

${ }^{15}$ E. PRZYWARA, Augustinus. Die Gestalt als Gefüge, Leipzig, 1934., 57-60.
} 
važnost katoličkoga, prvi važnost objektivnoga, a drugi nadilaženje herojskoga antropocentrizma u djetinjem duhu. ${ }^{16}$

Na reformacijsko načelo $\gg j$ jedino Bog sve « Przywara odgovara katoličkim načelom analogije, odnosno načelom $\gg$ Bog sve u svemu «. To znači da ništa stvoreno nije identično s Bogom (Bog u svakoj sličnosti s čovjekom uvijek u većoj nesličnosti), čime se čuva distanca Boga i stvorenja. Ali isto tako ta distanca nije apsolutna jer je sve stvoreno prispodoba i vidljivost Boga (Bog u svakoj nesličnosti ostaje sličan s čovjekom), što znači da nije moguće takvo odvajanje Boga i čovjeka koje bi, zapravo, nanovo završilo u identitetu jednoga i drugoga: $\gg$ jedino Bog sve $\ll=\gg$ jedino čovjek sve «. »Sličnost « upozorava na činjenicu Božje prisutnosti u svijetu i u čovjeku, koja nikad ne dopušta čovjeku da djeluje i misli bez Boga ili da se stapa s Bogom. U tom smislu »sličnost « jest izraz stvorenosti, ponizno prihvaćanje ovisnosti o prisutnom Bogu u svijetu i u vlastitom životu.

Rješenje dakle za odnos Boga i svijeta, Boga i čovjeka ne smije biti nekakav čisti Bog $\gg$ u nama $\ll$ niti čisti Bog $\gg$ iznad nas $\ll$, nego jedino Bog $\gg$ u nama i iznad nas $\ll .{ }^{17}$ Dok se protestantsko $\gg$ Bog iznad nas « preokreće $\mathrm{u}$ apsolutno $\gg$ Bog u nama «, $\mathrm{u}$ katolicizmu čovjek nikada nije samo $\gg$ ništica protiv Boga $\ll$, nego $\gg$ nešto pred Bogom «. U katolicizmu vrijedi i distanca spram distance: $\gg$ Ne smijem se toliko shvaćati kao 'ništica' spram Boga da Boga pretvaram u 'ja sve' svoje vlastite biti te tako ekstremnom distancom stvaram identitet. $\ll{ }^{18}$ Upravo takav odnos $\gg$ sličnosti u još većoj nesličnosti « (4. lateranski sabor) jest ono što u katolicizmu sprječava identitet, odnosno obrat od $\gg$ jedino Bog sve $\ll \mathrm{u} \gg$ jedino čovjek sve $\ll$. Prema Przywari, taj nagon za ekstremnom distancom u reformaciji nije ništa drugo nego zahtjev za identitetom: »U konačnici, čovjek se spram Boga pretvara u ništicu kako bi Boga u sebe usisao i time postao 'jednak Bogu' $\ll{ }^{19}$ Mogli bismo reći da se u toj rečenici sažima cjelokupna Przywarina kritika reformacije.

Ovdje možemo ukratko reći nekoliko riječi o tome kako njemački teolog shvaća kristologiju u kontekstu kritike reformacije. Naime, prema njemačkom teologu, za kršćane Isus Krist jest Bogočovjek, on nije apstraktni Bog kao u teopanizmu, gdje se on zapravo pretvara u neku vrstu $\gg$ očovječenoga Boga $\ll$, ali on nije ni običan

\footnotetext{
${ }^{16}$ Isto, 60s. Przywara i Nietzschea tumači u kontekstu protestantizma, kao protest protiv zakržljalosti ljudskoga u fanatizmu istočnoga grijeha i spiritualizma Luthera. E. PRZYWARA, Ringen der Gegenwart. Gesammelte Aufsätze 1922-1927, Augsburg, 1929., 169-179., posebice 175. O Kierkegaardu vidi također I. RAGUŽ, Bilješke o kršćanstvu u Dnevnicima Sørena Kierkegaarda, u: Teološki fragmenti I., Đakovo, 2016., 259-293.

${ }^{17}$ E. PRZYWARA, Der katholische Gedanke, 68.

${ }^{18}$ E. PRZYWARA, Ringen der Gegenwart, 498.

${ }^{19}$ Isto. Također isto, 245.
} 
čovjek kao u panteizmu, gdje se događa pobožanstvenjenje čovjeka. ${ }^{20}$ Krist je stoga uvijek $\gg$ u nama $\ll$, ali istodobno i Krist $\gg$ iznad nas $\ll$. Zato se u takvom katoličkom poimanju Isusa Krista ne može dogoditi ni pobožanstvenjenje stvorenja, ali ni razbožanstvenjenje stvorenja. ${ }^{21} \mathrm{U}$ katolicizmu se, nastavlja Przywara, uvijek kreće od pozitivnoga prema negativnom, nigdje Bog nije »jedino sve «. Naš pisac citira Tomu Akvinskoga: »Bog daje stvorenjima moć djelovanja ne zato što bi mu nešto nedostajalo, nego zbog svoje savršene punine koja je toliko dostatna da se svima priopćuje. ${ }^{22} \mathrm{U}$ reformaciji napetost se polova, božanskoga i ljudskoga, prekida jednostavnim identitetom $\gg$ jedino Bog sve $\ll$. U katolicizmu pak nema toga prekida napetosti u identitetu, nego $\mathrm{u}$ analogiji stalno ostaje napetost polova $-\gg$ sličnost $\mathrm{u}$ još većoj nesličnosti «. Ta je napetost za našega autora izraz poniznosti, »poniznosti prolaznoga stvorenja pred jedino bivstvenim Bogom $\ll$, dok sve ostale filozofije završavaju uvijek $\mathrm{u}$ »ethosu pobožanstvenjenoga ja ili počovječenoga Boga $\ll^{23}$.

Naposljetku i tragicizam, koji Przywara primjećuje u modernoj filozofiji i kulturi, također je posljedica nijekanja analogije, misaoni pokušaj da se čovjeka pretvori u Boga. Kako se to ne postiže, čovjeku ne preostaje ništa drugo doli golemi tragicizam koji je, zapravo, izraz oholosti »similis ero altissimo «. Nasuprot tragicizmu, čovjek pak u poniznosti, a to znači u najvećem pomilostovljenju, sebe spoznaje i priznaje čovjekom, onkraj »pobožanstvenjenoga čovjeka « ili »očovječenoga Boga $\ll^{24}$. Katolicizam je tako za njemačkoga isusovca $\gg$ profinjena sredina $\ll$ u napetosti oprječnoga, između razbožanstvenjenja i pobožanstvenjenja čovjeka. ${ }^{25}$

\section{Reformacija kao opasnost}

U kasnijim djelima Erich Przywara također kritički interpretira reformaciju slijedeći reformacijsko načelo $\gg$ jedino $\ll$. Uglavnom se donosi ista kritika reformacije, pri čemu je ona sada sustavnija negoli u ranijim djelima. Tako u djelu Razgovor izmedu Crkava reformaciju Przywara tumači kao »re-formu «, kao koncentraciju na izvornu $\gg$ formu kršćanstva, kojoj se reformacija želi povratiti. U tom smislu reformacija traži $\gg$ bit kršćanstva «, ono čisto, izvorno, idealno kršćanstvo, nasuprot povijesnomu kršćanstvu, njegovim mogućim i stvarnim zlouporabama. Stoga reformacija nije protest protiv određenoga vida Crkve, nego protiv »same povije-

\footnotetext{
${ }^{20}$ E. PRZYWARA, Der katholische Gedanke, 98.

${ }^{21}$ Isto, 100.

${ }^{22}$ E. PRZYWARA, Der katholische Gedanke, 83.

${ }^{23}$ E. PRZYWARA, Ringen der Gegenwart, 221.

${ }^{24}$ Isto, 373.

${ }^{25}$ Isto, 428.
} 
sno žive Crkve, ukoliko ona nije u skladu s idealnim 'prvotnim kršćanstvom' ${ }^{26}{ }^{26} \mathrm{Za}$ Przywaru reformacija podrazumijeva sljedeće:

Prvo, reformacija se predstavlja kao neka vrsta platonizirajućega kršćanstva, gdje vlada primat $\gg$ duha $\ll$ spram realnosti, $\gg$ čiste forme $\ll$ spram stvarnosti. U tom smislu reformacija je desperacio, očaj spram stvarnosti, prema našem autoru. Stvarnost je krajnje suprotna idealnoj formi kršćanstva. $\mathrm{Na}$ taj način nastaje »dijalektička distanca « $u$ reformaciji, distanca između svetoga Boga i grješnoga čovjeka. Ali ta distanca nije obično razlikovanje Boga i čovjeka, nego proturječje između Boga i čovjeka te Boga i svijeta. Stoga »čovjek, koji želi živjeti u Bogu, mora tako živjeti kao da nema svijeta, čovjeka i vidljivosti. A čovjek pak, koji želi živjeti u svijetu, mora tako živjeti kao da nema Boga $\ll{ }^{27}$. Dolazi do krajnjega suprotstavljanja Boga i svijeta. Tako nastaje i teologija koja se protivi svemu realnomu. Teologija milosti protiv teologije djela, kristologija križa protiv kristologije slave, tj. protiv teologije koja ima nakanu prožimati ovaj svijet snagom uskrsloga Krista; teologija Božjega kraljevstva protiv teologije kršćanskoga svijeta, odnosno protiv pozitivnoga uključivanja svijeta i povijesti u prostor vidljive Crkve. Przywara zaključuje da zbog toga ne treba čuditi da je reformacija isključila Blaženu Djevicu Mariju iz svoje misaone forme jer Blažena Djevica Marija upravo izriče Boga koji nije samo duh, nego Boga koji je uzeo stvarno tijelo, koji je ušao u povijest. Ne postoji više Bog »čiste forme $\ll$, nego Bog koji je uzeo formu ovoga svijeta.

Drugo, reformacija posebice stavlja u središte slobodu savjesti. Idealno kršćanstvo, svijest o »čistoj formi « kršćanstva negdje se mora čovjeku očitovati, a to je njegova nutrina, svijest, odnosno savjest. U tom smislu »čista forma k kršćanstva, njegov idealni lik, dolazi do izražaja u savjesti reformatora ili proroka općenito: »Subjektivna savjest toga reformacijskog, proročkog, protestantskog čovjeka shvaća se time gotovo kao postojeća savjest Crkve ili kršćanstva, ili čovječanstva općenito. $\ll^{28}$ Idealno kršćanstvo, njegova norma ne može se pojaviti u realnom, nego jedino u duhovnom, a to je čisti duh, savjest reformatora ili proroka. Tako nastaje reformacijsko shvaćanje savjesti kao duhovne stvarnosti, gdje dolazi zapravo do identiteta Božje »čiste forme « $\mathrm{i} \gg$ čiste forme « savjesti čovjeka: »Bog i forma te duh i nutrina stapaju se, dok se time obrnuto stvarnost, vidljivi svijet, izvanjsko pojavljuju kao 'tijelo grijeha.' ${ }^{29}$ Tako se rađa novovjekovno poimanje savjesti kao mjesta krajnje slobode od svega realnoga i postojećega: unutar prosvjetiteljstva savjest se shvaća kao suverenost čistoga ethosa, u racionalizmu kao suverenost čistoga uma, a u li-

\footnotetext{
${ }^{26}$ E. PRZYWARA, Gespräch zwischen den Kirchen, 10.

${ }^{27}$ Isto, 12.

${ }^{28}$ Isto, 20.

${ }^{29}$ Isto, $23 \mathrm{~s}$.
} 
beralizmu pak kao suverenost čiste čovječnosti. Reformacijski Bog-savjest postaje apsolutnost ljudske savjesti-forme, čiste savjesti-duha.

I u takvom poimanju ponovno, primjećuje naš autor, nedostaje Blažena Djevica Marija. Naime Blažena Djevica Marija kazuje katoličko poimanje savjesti, koje nije shvaćeno kao unutarnja suverenost i nedodirljivost spram stvarnosti, nego unutarnje služenje Bogu i izvanjsko služenje čovjeku, dakle upravo Marijino: »Evo službenice Gospodnje, neka mi bude po tvojoj riječi.« Nasuprot Bogu ne stoji jedan dio čovjeka, njegova nutrina, nego cijeli čovjek. U služenju dolazi do izražaja nasuprotnost Boga i čovjeka, personalna razlika koja ne dopušta identitet, ukinuće Boga u nutrini savjesti. Isto tako služenje je ono koje je univerzalno jer se ono ne tiče samo nutrine, nego svega stvarnoga, izvanjskoga i nutarnjega, duha i tijela, nevidljivoga i vidljivoga, nutrine i izvanjskoga djela. Ne postoji više nekakvo čisto služenje svijetu spram čistoga služenja Bogu, nego se Bogu služi u svemu i sa svim. Naposljetku reformacijsko poimanje savjesti uvijek je podređeno isključivo stanju čovjeka: »Kako ja dobivam milosnoga Boga? « Savjest u katoličkom shvaćanju promatra se opet kao služenje Bogu, služenje Bogu u svim stvarima, dakle savjest predstavlja odmak od samoga sebe i svojega vlastitoga stanja, od uskoće jednoga, napetoga između prestravljenosti i utješenosti. ${ }^{30}$

Treće, sličan problem nalazi se i u relativizaciji zakona, dogme u reformaciji. Protest reformacije događa se uvijek u ime »jedino Bog «: jedino Bog čiste ideje protiv $\gg$ iskvarene zbilje $\ll$, jedino čista nutrina protiv $\gg$ iskvarene vanjštine $\ll$. To isto Przywara uviđa i u kristologiji. Reformacijska kristologija stavlja naglasak na Isusa Krista kao Riječ, gdje slabo dolazi do izražaja njegova tjelesnost, njegovo čovještvo. Ista spiritualizacija reformacije (Bog i savjest) ponavlja se sada i u poimanju Isusa Krista. Krista se također naviješta $\mathrm{u} \gg$ čistoj riječi $\ll$, a odgovor na »čistu riječ « jest opet »čista vjera «. Tako se zapravo u reformaciji savršeno podudaraju: čisti Bog čiste nutrine (čiste savjesti) spram »čiste riječi $\ll$. Bog je i u Isusu Kristu »nutarnji Bog « $\mathrm{i} \gg$ duhovni Bog «. Kršćanstvo ne smije imati nikakve veze $\mathrm{s} \gg$ nečistim «, zakonom, dogmom, kršćanstvo jest »jedino evanđelje «. Riječ je o tome da se Isusa Krista treba susresti u njegovoj čistoći, kao čistu riječ koja sada i ovdje govori vjerniku, čisto i neposredno, slobodno od svakoga posredovanja, zakona ili dogme. Krist, kao Riječ, ne smije predstavljati nekakvu »supstancijalnost «, imati određeno ljudsko obličje, nego jest isključivo shvaćen kao »'aktualnost' žive Božje riječi koja odzvanja $\ll^{31}$.

\footnotetext{
${ }^{30}$ Isto, 32 .

${ }^{31}$ Isto, 38.
} 
Zato se u reformaciji i kult reducira na propovijed, a propovijed nije i ne smije biti objašnjenje objektivnih istina, zakona, nego jedino »navještaj riječi $\ll$. U tom smislu više ne postoji neka posredovana, »supstancijalna « instanca po kojoj bi čista riječ odjekivala, ne postoji više ni razlikovanje između Crkve koja podučava i Crkve koja sluša, nego isključivo Crkva kao mjesto aktualnoga navještaja koje se događa kao $\gg$ neposrednost između navještene riječi i slušajuće savjesti $\ll^{32}$. Takav navještaj nema nakanu uspostaviti potom nekakav zakon, dogmu, nego navještaj ima smisao u sebi samome, tako da je » zakon kršćanskoga poretka i kršćanskoga života 'nakon' opravdanja nezamisliv, jer se sav istinski 'kršćanski' život sastoji u uvijek iznova aktualnom događanju opravdanja $\ll^{33}$.

I tu se opet primjećuje marijanski nedostatak reformacije. Naime u Blaženoj Djevici Mariji Isus Krist nije »čista riječ«, nego Riječ koja je postala tijelom, Bog je postao supstancijalna stvarnost, ljudska narav. Krist ne dolazi nama u čistom obli$\mathrm{ku}$, nego uvijek u svojoj ljudskoj naravi, a time po onome tijelu koje je sjedinio sa sobom, a to je Crkva, Crkva kao »glava i tijelo, jedan Krist «. Zato je kršćanstvo i dogma, jer je Božja riječ zasijana u »njivu « čovjekova duha i povijesti, ona ne ostaje apstraktna, nego postaje konkretna. Također je, tvrdi Przywara, kršćanstvo i zakon jer »vječna riječ «, »vječna istina « ne ostaje po strani, nego upravo postaje i ostaje takvom što ulazi u ovaj svijet i ovaj život te ga želi prožeti »da stvarno 'postane tijelom' u svakom čovjeku, u cijelom njegovu životu i njegovu djelovanju: kao 'zakon života u Kristu' «. ${ }^{34} \mathrm{U}$ tom smislu Božja riječ jest dakako grom, nastavlja Przywara, ona udara na statični poredak vjere, Crkve i društva, »ali taj grom nije zbog samoga groma (aktualnost zbog same aktualnosti) «, nego u tom gromu jest $\gg$ Bog Stvoritelj, koji ‘zasvijetli na licu Kristovu', kao svjetlo koje stvara novost (2 Kor 4, 6) 'novoga stvorenja' $\ll .{ }^{35}$

Četvrto, reformacija ukida i nadomješta Crkvu, Božji autoritet, »Boga u Kristu u Crkvi « apsolutnim autoritetom »Boga u savjesti $\ll{ }^{36} \mathrm{Ne}$ postoji više Crkva koja podučava, nego samo Crkva koja sluša, tj. jedino čista vjera koja ima neposredan pristup čistoj Božjoj riječi. Dakle ulogu Crkve preuzima čista nutrina, čista savjest vjernika, u nutrini se događa jedinstvo vjernika i čiste riječi. Svaki pojedinac jest na neki način $\gg$ Crkva «, njemu je prepušteno da on osobno ostvaruje i aktualizira jedinstvo s Božjom riječi bez ikakva izvanjskoga posredovanja. Zato, zaključuje njemački teolog, Crkva se u reformaciji pluralizira, personalizira i aktualizira u osob-

\footnotetext{
${ }^{32}$ Isto, 39.

${ }^{33}$ Isto, 41.

${ }^{34}$ E. PRZYWARA, Gespräch zwischen den Kirchen, 43.

${ }^{35}$ Isto, 45.

${ }^{36}$ Isto, 51.
} 
noj savjesti aktualne vjere. U reformaciji se crkvenost živi iznutra, čisto i odvojeno od svijeta, ona ne smije imati nikakva kontakta s ovozemaljskom stvarnošću koja je nečista i iskvarena te koja takva ne može više biti sakrament, reprezentacija samoga Boga.

No, prema Przywari, reformacija ne uspijeva uvidjeti da smisao Crkve, kao zajednice koja sakramentalno predstavlja Boga, nije u njezinoj čistoći, nego upravo u njezinoj prljavštini. Crkva čini ono što je Krist činio, a to je da nosi i podnosi grijehe ovoga svijeta. Stoga vjernik ne ostvaruje svoj odnos prema Kristu čisto osobno i aktualno bez Crkve, što bi bila neka vrsta sebičnoga ostvarenja vjere, nego upravo u Crkvi, u kojoj su svi, po različitim službama (hijerarhiji također) uzajamno povezani, povezani u jednom Tijelu, Kristovu Tijelu koje je Crkva. Zato će Przywara u mnogim svojim tekstovima uvijek iznova isticati da su upravo grijesi, tame i prljavštine Crkve dokaz toga da je ona Kristova Crkva, da ona čini ono što je Krist činio: njezin je kenosis, sebe-poništenje kada preuzima grijehe poradi nas, kada »sama sebe u improperijama Velikoga petka optužuje u cijelosti kao 'narod moj' Božjega ubojstva (kao što Izrael sebe priznaje takvim u improperijama), i koja se u svakodnevici Velikoga petka optužuje kako bi jedino tako slobodno primila 'slavu sretne krivnje' svakodnevne uskrsne noći ${ }^{37}$.

Odnos se dakle prema Kristu, kako će to kasnije pokazati Przywara protiv Luthera, ne ostvaruje »nago «, nego uvijek konkretno, u stvarnom životu Crkve. U reformaciji također i opravdanje bez Crkve ostaje apstraktno, duhovno, ono ne zahvaća cijeloga čovjeka i cijeli svijet, što se upravo događa u Crkvi. Zato postaje opet razumljivo zašto i ovdje reformaciji nedostaje Blažena Djevica Marija.

\section{Reformacija i Martin Luther kao ekumenski izazov}

Nakon što smo prikazali Przywarinu kritiku reformacije, sada ćemo ukratko progovoriti o njegovu pozitivnom doprinosu reformacije i teologije Martina Luthera, kao i njihov ekumenski izazov za Katoličku Crkvu.

U djelu Stari i novi savez za Przywaru pozitivnost reformacije krije se upravo u njezinu negativnom, rušilačkom aspektu spram europske povijesti. Naime reformacija je uzdrmala i poništila tri stupa europske kulture, kulture koja počiva, zapravo, na samoj ideji kršćanstva: jedna Crkva, jedna država i jedno kraljevstvo. Reformaciju njemački teolog shvaća kao protest protiv jedne Crkve, Kristova Tijela koje se otudilo od sebe samoga i od Isusa Krista. Tako jedna Crkva postaje $\gg$ Ecclesia dilacerata $\ll$, pocijepana Crkva među raznim Crkvama. Reformacija je i protest protiv jedne Božje države koja se također pretvorila u svoju suprotnost, te s reformacijom dolazi

${ }^{37}$ Isto, 62 . 
do sukoba, prijepora, podjela i mrcvarenja među kršćanskim narodima. Naposljetku reformacija je i protest protiv svetoga kraljevstva koje je postalo svoja krajnja suprotnost. Pod svetim kraljevstvom naš pisac misli na sklad božanskoga i svjetskoga, gdje kozmos sjaji prisutnošću samoga Boga u sakramentima. Sada kozmos gubi svoj sjaj, svijet postaje isključivo svjetski, svi se ovosvjetski elementi sekulariziraju, svijet kao da se pretvara $\mathrm{u} \gg$ jedan jedincati pakao razularenih elemenata, paklena voda, pakleni oganj, pakleni sumpor, jedna jedincata kemija razularenih elemenata $\ll^{38}$.

Dakle reformacija predstavlja krizu i neuspjeh poslanja Europe, Zapada. Europi, Zapadu, događa se nešto slično, smatra naš pisac, kao i poslanju koje je imao izraelski narod. Naime izraelski narod također je bio jedno, odnosno imao je svoje kraljevstvo i neovisnost, ali se raspao i podijelio u fragmente, postavši dijaspora. ${ }^{39}$ U tom smislu Przywara ne tumači isključivo negativno ono što se dogodilo Zapadu s reformacijom. Ona je na neki način posljedica oholosti zapadne kulture. Zato reformacija nije Božji neuspjeh, nego Božje »'ecce nova facio omnia', kako bi kršćanska tradicija koja je postala ohola, Kristovo tijelo koje je postalo oholo i okoštalo, ostarjelo Sveto kraljevstvo, zastarjeli božanski kozmos prošao kroz Božji oganj: 'Deus noster ignis consumens est: naš Bog je oganj koji proždire.' $\ll{ }^{40}$. Kriza i raspad jedinstva Zapada i zapadnoga kršćanstva za Przywaru je prigoda za novo kršćanstvo, za novo poimanje i same zapadne kulture.

I u ovom djelu ponovno susrećemo već uobičajenu kritiku reformacije našega autora koji reformaciju promatra pod četverostrukim vidom isključivosti.

Tako prva isključivost $\gg$ jedino grijeh « predstavlja dobar korektiv spram katoličkoga poimanja Crkve, gdje se Crkva lako može shvaćati kao sakralno čisti bitak, kao neka vrsta čisto preobraženoga sudioništva u samome Bogu. No korektiv se potom izokrenuo i otišao u svoju krajnost, postao je protestirajući ne: ne svijetu kao takvo$\mathrm{mu}$, pri čemu je svijet prepušten svojemu zlu.

To vrijedi i za reformacijsko načelo $\gg$ jedino savjest $\ll$. I tu je reformacija dobar korektiv spram Crkve koja se stavlja između Boga i pojedinca, i to tako da postaje svrha samoj sebi: »Životni Bog biva vezan uz hijerarhijsko stupnjevanje nebeskoga i zemaljskoga dvora, a životni čovjek objektivizira se u činovnika takve stupnjevite kurije. $\ll{ }^{41}$ Ali i tu reformacija od korektiva postaje protestirajuće ne svemu izvanjsko-

\footnotetext{
${ }^{38}$ E. PRZYWARA, Alter und Neuer Bund. Theologie der Stunde, Wien - München, 1956., 41.

${ }^{39}$ Vidi posebno E. PRZYWARA, Logos - Abendland - Reich - Commercium, Düsseldorf, 1964., 98101.

${ }^{40}$ E. PRZYWARA, Alter und Neuer Bund. Theologie der Stunde, 41.

${ }^{41}$ Isto, 45.
} 
mu, svakoj izvanjskoj formi i vidljivomu autoritetu. Nastaje nutrina koja bezlično leluja, čisto autonomna intuicija te apsolutni dinamizam nutrine.

Također se isto primjećuje i u načelu »jedino riječ«. I tu je reformacija istinski korektiv spram Crkve, kao hijerarhije svetoga bitka, koja potiskuje živu Božju riječ $\mathrm{u}$ korist svetoga tijela i stvari. Ali i tu reformacija prelazi granicu te želi sada $\gg$ jedino riječ $\ll, ~ \gg j e d i n o$ duh $\ll$. Tako nastaje čisti spiritualizam te čisti intelektualizam u reformaciji, gdje spoznaja postaje isključiva mjera svega zbiljskoga. Time također nastaje i problematicizam i dijalekticizam reformacije, što za našega pisca znači da se riječi u cijelosti odvajaju od stvarnosti. One postaju bestjelesne, ne izviru više iz Boga kao Riječi, stavljaju se na mjesto samih stvari, dakle beskonačno problematiziranje i dijalektiziranje riječi: »Bog Riječi nalazi se na početku kršćanskoga. Na izlazu novovjekovlja stoji riječ kao Bog. ${ }^{42}$

Naposljetku to vrijedi i za načelo $\gg$ jedino Krist $\ll$. I tu je reformacija korektiv prema Crkvi, čiji se hijerarhijski poredak bitka i svijeta bitka može izroditi u naravni poredak ovoga svijeta ili u posvjetovnjačenu instituciju koja, umjesto da bude propusna prema božanskom svijetu, prema Kristu, postaje svrha samoj sebi. I takav pak pristup Kristu završava u protestirajućem ne. Krist, koji se isključivo tumači pod vidom opravdanja grješnika, lišen je svakoga posredovanja objektivnoga, crkvenoga, postaje na neki način funkcija samoga čovjeka, Krist postaje »Božja forma čovjeka. Bog se u Kristu razvlašćuje kao forma čovjeka te se čovjek u Kristu razvlašćuje kao čisti nositelj te iste forme $\ll$, dakle dolazi do identiteta Krista i čovjeka, svaki je čovjek Krist, »Bog-čovjek postao je čovjek-Bog ${ }^{43}$.

No, premda su načela reformacije u svojoj isključivosti negativna i neprihvatljiva, ako ih se shvati kao korektiv ${ }^{44}$, tada ona imaju i trebaju imati golemu ekumensku važnost, kao način korekcije i Katoličke Crkve, ali i Crkava nastalih iz baštine reformacije.

${ }^{42}$ Isto, 47. Przywara je dobro uvidio posebnost reformacije kao kršćanstva riječi. Nije teško ne uvidjeti u običnoj svakodnevici kako su protestanti daleko veći »znalci riječi«, bolji govornici, gdje daleko više pozornosti i truda polažu na riječi, na njihov izričaj, njihovo djelovanju, na cjelokupni scenski okvir samoga čina govora. U katolicizmu postoji golema sumnja spram takvoga pristupa riječi i govoru, u smislu da se subjekt takvih riječi udaljuje od Božje Riječi, kao i od samih stvari, objekata ovoga svijeta. U središtu je subjekt, subjektivno, a ne objekt, objektivno.

${ }^{43}$ E. PRZYWARA, Alter und Neuer Bund. Theologie der Stunde, 49.

${ }^{44}$ Przywara preuzima uglavnom Kierkegaardovo shvaćanje reformacije koja ima smisao samo kao korektiv, ali nikako kao norma kršćanstva. Vidi E. PRZYWARA, Das Geheimnis Kierkegaards, München - Berlin, 1929. Vidi također I. RAGUŽ, Bilješke o kršćanstvu u Dnevnicima Sørena Kierkegaarda, 278ss. 
Tako načelo »jedino grijeh « jest poticaj da jedni i drugi ponovno otkriju važnost obraćenja, obraćenja od ohole svijesti pravednika prema ispovijesti onoga siromašnoga carinika u hramu. To se posebice odnosi na Katoličku Crkvu. No nije dovoljno samo obraćenje, potrebno je prihvatiti da načelo $\gg$ jedino grijeh $\ll$ još ne predstavlja Božje kraljevstvo, da je potrebno učiniti još jedan korak, a to je korak prema Crkvi kao $\gg$ istinskom bitku od Boga i bitku u ovom svijetu «. Tako se Crkva i reformacija susreću u tom istinskom confiteor, i to u onom trenutku povijesti kada je $\gg$ prokletstvo posvjetovnjačenja i iskvarenosti te demoniziranja svijeta postalo potpuno $\ll{ }^{45}$. Drugim riječima, Crkva i reformacija jedino tako mogu donositi Krista u ovaj svijet, inače vjera postaje dijelom ovoga svijeta (Katolička Crkva) ili ostavlja svijet u njemu samom bez Crkve (reformacija).

Načelo $\gg$ jedino savjest « za Katoličku Crkvu velik je poticaj da otkrije važnost osobne odluke. No današnji individualizam, koji se izrodio u čisti egoizam, pokazuje reformaciji da se takav sebični individualizam može prevladati jedino otkrićem Crkve. Tako se i u ovom načelu susreću Crkva i reformacija: Kristov poziv okrenut je pojedincu, ali pojedincu koji ne treba slušati Crkvu kao Boga, nego Krist zove »svakoga već kao nastajuću Crkvu, jer ih zove kao sluge, prijatelje, braću, udove samoga sebe, koji je vidljivi učitelj i Gospodin i Glava, kao što je Bog nevidljiva istina i gospodstvo i visočanstvo ${ }^{46}$. Dakle sebični egoizam, »sotonska moć razularenoga ja $\ll{ }^{47}$ ne može se prevladati samo pozivanjem na autoritet Crkve. Potrebna je osobna odluka, osobno življenje vjere. Međutim vrijedi i obratno, osobno življenje nije dostatno bez stvarnoga življenja te iste odluke u konkretnosti ljubavi, a to je upravo Crkva.

I počelo $\gg$ jedino riječ $<$ treba ujediniti Crkvu i reformaciju u vremenu $\gg$ sotonske magije jedino kreativne riječi čovjeka « koja razara Božji svijet i zamišlja čisti svijet čovjeka, svijet koji nastaje isključivo iz čovjeka. To se može postići jedino ako Crkva otkrije živu riječ u liturgiji, u navještaju, da sakramentalni život ne postane mrtvo događanje koje je ugušilo živi razgovor Boga i čovjeka. Ali i reformacija treba otkriti važnost tjelesnosti, vidljivosti, a time sakramentalnosti riječi, da se riječ ne pretvori u puki $\gg$ razgovor «, nego da upravo po svojoj vidljivosti i sakramentalnosti zadobije objektivnost. Tako će i Crkva i reformacija ostvarivati samu logiku utjelovljenja, a ta je da je Riječ postala tijelom, posebice danas, u vremenu »sotonske magije $\ll$ ljudskih riječi.

\footnotetext{
${ }^{45}$ E. PRZYWARA, Alter und Neuer Bund. Theologie der Stunde, 52.

${ }^{46}$ Isto, 53.

${ }^{47}$ Isto.
} 
Naposljetku načelo »jedino Krist « protivi se današnjemu pobožanstvenjenju čovjeka, gdje čovjek sebe stavlja na mjesto samoga Boga. Za Crkvu je to poticaj da se Krista počinje shvaćati i živjeti egzistencijalno, gdje ne postoji više Bog u sebi i čovjek u sebi, nego jedino Krist koji objedinjuje božansko i ljudsko. No nije dovoljan samo osobni Krist, kao što je to prije bio slučaj u reformaciji. Potreban je danas isto tako i Krist Crkve, Krist koji obuhvaća i pojedinca i državu, i državu i kraljevstvo, i kozmos. Jedino tako Krist će ostati osoban, a opet tako osoban da nije reduciran na čovjekovu osobnost.

Tako na kraju zapadne kulture, smatra Przywara, u uzajamnoj ekumenskoj otvorenosti Katoličke Crkve i reformacije može nastati nova zapadna kultura, novi Zapad: »Jedan pastir i jedno stado i jedan ovčinjak kao jedan Krist, duša i Crkva, i država, i kraljevstvo, i kozmos jedan Krist, Glava i Tijelo jedan Krist. $\ll^{48}$

Ekumenski se izazov također krije i u samoj teologiji Martina Luthera. Kako sam Przywara piše ${ }^{49}$, novost njegova razumijevanja reformacije jest osobito u tumačenju teologije Martina Luthera. Przywarino tumačenje Lutherove teologije također ima veliku ekumensku vrijednost, ako ono predstavlja golemu kritiku određenih težnji u katolicizmu i protestantizmu nakon 2. svjetskoga rata, težnji koje se i danas bitno nisu promijenile, a što pokazuje svu aktualnost Przywarinih promišljanja. No pogledajmo najprije kako Przywara tumači Luthera. ${ }^{50}$

Przywara najprije uspoređuje Melanchtona i Luthera. Nasuprot Melanchtonu, koji vjeru reducira na solum fiducijalne vjere spram solum Božje milosti ili riječi, Luther vjeru oslobađa od toga subjektivnoga i smješta ju u kontekstu »obećanja «. Vjera se odnosi uvijek na objektivnost obećanja Staroga zavjeta sve do Krista, kao i na objektivnost Kristovih obećanja sve do njegova drugoga dolaska. Luther također ističe objektivnost ženidbenoga zajedništva Krista i Crkve. A ono pak najvažnije, čime Luther prevladava subjektivnu i idealističku korelaciju vjere, milosti i Riječi, jest ženidbena razmjena božanskoga i ljudskoga, u skladu s 2 Kor 5, 18-20: »A sve je od Boga koji nas sa sobom pomiri [kata-llage - razmijeni] po Kristu i povjeri nam službu pomirenja. Jer Bog je u Kristu svijet sa sobom pomirio ne ubrajajući im opačina njihovih i polažući u nas riječ pomirenja.«

Upravo u toj dimenziji Przywara primjećuje »iskonskoga Luthera «, njegovu posebnost koju još ni sami protestantski teolozi nisu uočili, a što je za samoga Przywaru važno, osobito za njegovo shvaćanje kršćanstva. Dakle riječ je o tome da je Luther, na tragu crkvenih otaca, stavio u središte svojega razumijevanja odno-

\footnotetext{
${ }^{48}$ Isto, 56.

${ }^{49}$ E. PRZYWARA, Gespräch zwischen den Kirchen, 72.

${ }^{50}$ E. PRZYWARA, Humanitas. Der Mensch gestern und morgen, Nürnberg, 1952., 376-415.
} 
sa Boga i čovjeka ženidbenu razmjenu na križu, kao »admirabile commercium « božanskoga i ljudskoga $\mathrm{u}$ raspetom Isusu Kristu. ${ }^{51}$ Dakle $\mathrm{u}$ »čudesnoj razmjeni« božanskoga i ljudskoga Bog postaje čovjekom kako bi čovjek postao Bogom, u središtu je uzajamni kenosis: sebe-poništenje Boga s jedne strane, a s druge pak strane sebe-poništenje čovjeka. Čovjek može doći Bogu samo po sebe-poništenju. Przywara donosi sljedeći Lutherov tekst: »Zato 'Bog ne može postati mudrim, pravednim, istinitim, hrabrim, dobrim itd. u svojim govorima, ako mi, njemu vjerujući i spram njega uzmičući, nismo nemudri, nepravedni, lažni, slabi, zli'.« ${ }^{52}$ Time je prevladana Melanchtonova subjektivistička i idealistička korelacija vjere i milosti. Bog ne stoji statično spram čovjeka, a ni čovjek statično spram Boga. Ne postoji redukcija Boga na subjekt vjere jer je čovjek u Kristu tako zahvaćen Bogom da izlazi iz sebe, da sebe poništava u Isusu Kristu.

Lutherov ženidbeni »admirabile commercium « protivi se također i kalvinističkom protestantizmu, u kojemu se svijest o posebnosti Božjega izabranja svodi na uspješnost djelovanja u ovom svijetu. U Luthera se izabranje ostvaruje kao kenosis, kao sebe-poništenje, kao sebe-poništenje u služenju drugomu, a ne u uspješnosti ovoga svijeta: »Time se (zapravo onaj pravi) 'muzički' Luther Pjesme nad pjesmama neumoljivo suprotstavlja romanskomu pravniku Calvinu: Luther 'djeteta' i 'križa' od tijela i krvi protiv 'božanskoga visočanstva koje stoluje u visinama.' ${ }^{53}$ Dakle opet »admirabile commercium « prevladava distancu između Boga i čovjeka, i to takvu distancu, kako smo već pokazali, koja za Przywaru uzrokuje identitet Boga i čovjeka.

Prema njemačkom teologu, sekularizirani protestantizam nastao je, zapravo, zbog zaborava Lutherove teologije ženidbene razmjene. On je nastao kao neka vrsta »posredničke tvorevine « koja je imala ulogu pomirljivo posredovati između »ubojite oprječnosti « melanchtonskoga i kalvinističkoga protestantizma. Tako nastaje ideja $\gg$ prirodne religije $\ll i ~ i p$ prirodnoga morala $\ll 18$. i 19. stoljeća (prosvjetiteljstvo, humanizam i racionalizam). K tomu se pridružuje ideja »germanskoga protestantizma « koji kršćanstvo reducira na germanski ethos nastajanja, odnosno na $\gg$ faustovsku kršćansku religioznost «, a to je razlog određenih pokušaja »unije « između katolika i protestanata, u razdoblju između dvaju svjetskih ratova. ${ }^{54} \mathrm{U}$ svim tim pokušajima promašuje se ono što je bit kršćanske vjere, a što je Luther istaknuo svojom teologijom ženidbene razmjene božanskoga i ljudskoga u Isusu Kristu, a to je dinamika sastajanja i rastajanja (Begegnung-Entgegnung), bliskosti i distance,

\footnotetext{
${ }^{51}$ Isto, 379s. Također E. PRZYWARA, Katholische Krise, Düsseldorf, 1967., 207s.

${ }^{52}$ E. PRZYWARA, Humanitas. Der Mensch gestern und morgen, 380.

${ }^{53}$ Isto, 383.

${ }^{54}$ Isto, 385.
} 
grijeha i milosrđa. Time Przywara želi reći kako se u ženidbenoj razmjeni događa neizmjerna bliskost (sastajanje: Bog je postao čovjekom), ali i golema distanca (rastajanje: čovjek je grješnik spram Boga). U Lutherovoj teologiji nema mjesta za melanchtonovski redukcionizam vjere na nutrinu, a ni za kalvinistički redukcionizam na udaljenoga Boga suverenoga veličanstva. U Luthera se spasenje shvaća kao oprječnost, kao razotkrivanje čovjeka kao grješnika, ali gdje Bog u ženidbenoj razmjeni postaje grješnikom poradi čovjeka. Tako dolazi do izražaja i druga dimenzija Lutherove teologije, a to je $\gg$ sub contraria absconditum $\ll$. Bog u Isusu Kristu ostaje skrivenim upravo u toj ženidbenoj razmjeni, njega se jedino može ispravno razumjeti u tome sebe-poništenju.

Ne ulazeći u slojevita tumačenja Lutherove teologije našega pisca, zaključno se može reći da je Przywari stalo istaknuti kako je, zapravo, sama Lutherova teologija golema kritika reformacije. U pozadini je Przywarina kritika reformacije koja svojom logikom »jedino Bog sve «, odnosno logikom proturječja Boga i čovjeka, uzrokuje zapravo identitet, redukciju Boga na čovjeka. Lutherova pak teologija ženidbene razmjene to ne dopušta jer je čovjek stavljen u dinamiku Kristove razmjene, u dinamiku napuštanja samoga sebe, u dinamiku sebe-poništenja koje jedino dovodi do zajedništva s Bogom, zajedništva u kojemu nije moguć identitet, nego sastajanje (»sličnost s Bogom «) i rastajanje ( $\gg$ u još većoj nesličnosti s Bogom «), što je bit ljubavi shvaćene kao »agape «, kako ju vidi Przywara.

No, prema našem piscu, takav »iskonski Luther « predstavlja i kritiku modernoga protestantizma i katolicizma, kod kojih uviđa dva temeljna pristupa svijetu: ili radikalno odreknuće od svijeta ili kršćansku preobrazbu svijeta. ${ }^{55} \mathrm{U}$ prvom bi to značilo bijeg iz svijeta, dakle odbacivanje ženidbene razmjene, u kojoj je Bog u Isusu Kristu ušao u svijet i sebe poništio. U kršćanskoj pak preobrazbi stvara se paralelan sakralni svijet (liturgija, Crkva) koji se opet odvaja od stvarnoga života. Jednoj i drugoj težnji Przywara suprotstavlja iskonskoga Luthera, a time i sve teologe ženidbene razmjene u povijesti Crkve, dakle Boga koji se lišava svoje $\gg$ čiste forme $\ll i$ ulazi u formu ovoga svijeta. $S$ druge pak strane Przywari je na taj način strano svako poistovjećivanje Crkve i svijeta, vjere i razuma, jer ženidbena razmjena naznačuje distancu, $\gg$ rastajanje «, a time i zahtjev za kenozom, sebe-poništenjem svijeta i razuma u vjeri u Isusa Krista. Jednom riječju, našemu je piscu strano svako getoizirano kršćanstvo, ali i svako posvjetovnjačeno, puko humanističko kršćanstvo. Posebice je to drugo istaknuo Hans Urs von Balthasar tvrdeći da je Przywarina misao neka vrsta korektiva za Crkvu nakon 2. vatikanskoga sabora, u kojoj je preslabo dolazio, a i danas također preslabo dolazi do izražaja »elementarni, upravo starozavjetni

${ }^{55}$ E. PRZYWARA, Gespräch zwischen den Kirchen, 76.; Alter und Neuer Bund. Theologie der Stunde, 61-64. 
smisao za božanstvenost Boga koji je oganj koji proždire, mač koji ubija i ljubav koja otima $\ll^{56}$.

Kao zaključna misao, glede Przywarina tumačenja Lutherove teologije kao kritike današnjega katolicizma i protestantizma, vrijedi sljedeće: $\gg S$ tim vrijedi strogi iliili: ili će protestantizam i katolicizam posegnuti za tim Lutherom križa, razmjene, ženidbe i Marije kao istinsko zajedničkoga, ili će oba, bilo katolički evangelicitet, bilo evangelički katolicitet, propasti u sanjarsko, modernističko, eshatološko kršćanstvo, koje je kao bijeg od križa zapravo i bijeg od svijeta. ${ }^{57}$

Ipak, Przywara ne propušta kritizirati Lutherovu teologiju. Luther je, doduše, ispravno stavio u središte Kristov križ, shvaćen kao ženidbenu razmjenu Boga i čovjeka. No, nažalost, Luther je Kristov križ učinio »nagim «, a to znači da mu je oduzeo realnost. Pod realnošću Przywara misli na stvarno življenje Kristova križa, stvarnu patnju križa, a to je život u Crkvi. Misli se na realno, konkretno življenje Kristova križa u Kristovu Tijelu, koje je Crkva. Premda se svojom teologijom križa Luther radikalno protivi spiritualizmu i maniheizmu albigenza, ipak njegova teologija »nagoga križa « uzrokuje razorni eshatologizam, koji poništava »realnost « življenja vjere, eshatologizam, u čijem ognju sam Zapad gori i izgara, eshatologizam koji je »zapalio oganj pobune protiv svake vidljive Božje slave na zemlji, te čije djelo dovršava Nietzscheov 'dinamit' i Bakunjinova 'pobuna' $\ll .{ }^{58}$ Martinu Lutheru, tvrdi naš pisac, nedostaje poniznosti, u njemu prevladava jednostrano antipelagijanski Augustin, ali ne i onaj antidonatistički Augustin, Augustin čudesne poniznosti podnošenja $\gg$ nesvete braće $\ll 59$.

Imajući u vidu promišljanja Ericha Przyware o reformaciji i teologiji Martina Luthera, Przyware koji je na hrvatskom govornom području gotovo u cijelosti nepoznat, vjerujemo da njegova misao može i treba pridonijeti boljemu razumijevanju katolicizma i protestantizma, ali i njihovu ekumenskom dijalogu, koji Przywara shvaća kao dijalog koji se događa u razlikama i oprječnostima.

\footnotetext{
${ }^{56}$ H. U. v. BALTHASAR, Erich Przywara, 354.

${ }^{57}$ E. PRZYWARA, Katholische Krise, 210., također 203., 207.

${ }^{58}$ E. PRZYWARA, Humanitas. Der Mensch gestern und morgen, 400. Također Gespräch zwischen den Kirchen, 77.

${ }^{59}$ E. PRZYWARA, Katholische Krise, 101.
} 


\title{
ERICH PRZYWARA ON THE REFORMATION
}

\author{
Ivica RAGUŽ
}

Summary: The article presents Erich Przywara's reflections on the Reformation. The first part brings Przywara's understanding of the Reformation in his earlier works under the aspect of 'Only God everything', that is, the Reformation understood as 'theopanism'. For the German theologian such an approach leads to anthropocentrism and cosmocentrism, to the abolition of God, to the identification of God with man's 'I' or with the world. The second part analyzes the critique of the Reformation in Erich Przywara's later works. It also touches on his reflections on analogy, Catholic Christology and Mariology as a response to the theological settings of Reformation. The third part presents a positive interpretation of the Reformation and the theology of Martin Luther. Przywara understands the Reformation as a corrective to Catholicism, but also as a challenge, which in ecumenical dialogue with Catholicism, understood as a dialogue of differences and contrasts, can help to renew and rejuvenate Christianity, especially in Europe.

Keywords: Erich Przywara, Reformation, Martin Luther, Catholicism, Protestantism, Modernity.

* Full Prof. Ivica Raguž, Ph. D., Catholic Faculty of Theology in Đakovo, J. J. Strossmayer University of Osijek, P. Preradovića St 17, P. O. box 54, 31400 Đakovo, Croatia, ivica.raguz@os.t-com.hr 